УДК 616.12-008.318-085-089

DOI: $10.26435 /$ UC.V0I4(33).328

\author{
Н.Т. Ватутин ${ }^{1,2}$, Г.Г. Тарадинн ${ }^{1,2}$, Н.О. Реутова ${ }^{1}$ \\ ${ }^{1} Г 00$ ВПО «Донецкий национальный медицинский университет имени М. Горького», Донецк \\ 2ГУ «Институт неотложной и восстановительной хирургии им. В.К. Гусака», Донецк
}

\title{
МЕДИКАМЕНТОЗНАЯ ТЕРАПИЯ В ЛЕЧЕНИИ И ПРОФИЛАКТИКЕ ЖЕЛУДОЧКОВЫХ АРИТМИЙ И ВНЕЗАПНОЙ СЕРДЕЧНОЙ СМЕРТИ
}

Жизнеугрожающие желудочковые аритмии (ЖА), такие как устойчивая желудочковая тахикардия (ЖТ) и фибрилляция желудочков (ФЖ), ответственны за 2/3 случаев внезапной сердечной смерти (BCC) [1]. Поскольку патогенез многих желудочковых тахиаритмий довольно хорошо изучен, теоретически можно предположить, что лекарственное вмешательство с помощью антиаритмического препарата (ААП) нейтрализует аритмию и предупредит ВСС.

Кроме того, поскольку в большинстве случаев аритмогенез связан с повышением автоматизма, нарушением проводимости, негомогенной реполяризацией миокарда, механизмом reentry и другими электрофизиологическими нарушениями, лекарственные вещества [2], которые непосредственно влияют на электрофизиологические процессы на клеточном и тканевом уровне (ААП), должны предоставлять возможность предотвратить, купировать, замедлить или, в целом, противодействовать ЖА [1].

Характеристика антиаритмических препаратов

В настоящее время, несмотря на отсутствие достаточного количества многоцентровых рандомизированных исследований, ААП широко назначаются для лечения и профилактики ЖА и BCC [3-5].

Согласно классификации Vaughan Williams [6] выделяют четыре класса ААП:

I класс - блокаторы натриевых каналов клеточной мембраны кардиомиоцитов (средства, действующие на натриевые каналы); подкласс IA - умеренно замедляющие скорость деполяризации и реполяризации (хинидин, новокаинамид, дизопирамид и др.); IB - незначительно замедляющие скорость деполяризации и ускоряющие реполяризацию (лидокаин, тримекаин, мексилетин, дифенин); IC - выраженно замедляющие скорость деполяризации и влияющие на реполяризацию (пропафенон, флекаинид, энкаинид, аллапинин);
II класс - $\beta$-адреноблокаторы ( $\beta$-АБ, пропранолол, бисопролол, атенолол, метопролол, карведилол и др.);

III класс - препараты, удлиняющие реполяризацию и действующие на калиевые каналы (амиодарон, соталол и др.);

IV класс - блокаторы кальциевых каналов (верапамил и дилтиазем).

\section{1. Антиаритмические препараты I класса}

Среди блокаторов натриевых каналов клеточной мембраны кардиомиоцитов для борьбы с ЖА успешно используют лидокаин [7], мексилетин (при врожденном синдроме удлиненного интервала QT) [8], хинидин (у пациентов с синдромом Бругада) и флекаинид (у больных с катехоламинергической полиморфной желудочковой тахикардией) [9]. Другие препараты этого класса имеют слабую (или негативную) доказательную базу как в лечении, так и профилактике таких аритмий. В то же время, ААП класса IC (флекаинид, пропафенон) противопоказаны при наличии структурных заболеваний сердца (особенно после инфаркта миокарда) $[5,10]$.

Как оказалось, ранолазин, предложенный в качестве антиангинального агента, также обеспечивает и блокаду натриевых каналов клеточной мембраны кардиомиоцитов в комбинации с блокадой реполяризующего тока калия; также стал использоваться как антиаритмическое средство при ЖА, в частности, при остром коронарном синдроме и инфаркте миокарда (ИМ), а также для снижения частоты разрядов имплантируемых кардиовертеров-дефибрилляторов $[11,12]$. Появились данные, что ранолазин хорошо переносится больными и эффективен при ЖА, рефрактерных к лечению стандартными ААП, благодаря снижению эпизодов ЖА и частоты разрядов имплантируемых кардиовертеровдефибрилляторов [13].

(c) Н.Т. Ватутин, Г.Г. Тарадин, Н.О. Реутова, 2019 (c) Университетская Клиника, 2019 


\section{2. Антиаритмические препараты II класса}

Благодаря хорошему профилю безопасности и эффективности, а также способности положительно влиять на основную кардиальную патологию, $\beta-А Б$ часто являются препаратами первой линии в лечении ЖА [14]. Их антиаритмическая активность связана с блокадой адренергических рецепторов, снижением активности синусового узла и, возможно, с другими механизмами [15]. $\beta$-АБ заметно снижают смертность от всех причин у пациентов с хронической сердечной недостаточностью (ХCH) со сниженной фракцией выброса (сФВ), перенесших ИМ и страдающих различными структурными заболеваниями сердца [15]. При использовании $\beta-А Б$ в комбинации с ААП, стабилизирующими мембрану, они заметно усиливают антиаритмическую эффективность [16]. $\beta$-АБ (к примеру, надолол, пропранолол) также являются базовыми средствами в терапии некоторых сердечных каналопатий (например, синдром удлинённого интервала QT, катехоламинергическая полиморфная ЖТ) $[17,18]$.

\section{3. Антиаритмические препараты III класса}

Амиодарон, как наиболее изученный препарат этого класса, обладает широким спектром действий, которые включают блокаду $\beta$-адренорецепторов, токов натрия, кальция и калия клеточных мембран кардиомиоцитов. Несколько исследований и мета-анализ показали снижение ВСС при использовании амиодарона у пациентов с дисфункцией левого желудочка, обусловленной перенесенным ИМ, или неишемической кардиомиопатией [19], хотя у лиц с ХСН со сФВ такого эффекта не наблюдалось. Кроме того, внутривенное введение амиодарона играет положительную роль в заметном уменьшении эпизодов рецидивирующих ЖТ и ФЖ во время реанимации $[20,21]$.

\section{4. Антиаритмические препараты IV класса}

В связи с сомнительной эффективностью и высоким риском осложнений, препараты этого класса редко используются при лечении ЖА. Так, попытки внутривенного введения верапамила при устойчивой ЖТ, ассоциировались с развитием кардиогенного шока, особенно у пациентов с предшествующим ИМ. Их опасно использовать и у больных с ЖА на фоне ХCH со сФВ, хотя пероральное и внутривенное применение верапамила достаточно эффективно при лечении идиопатической интерфаскулярной reentry левожелудочковой тахикардии [22].

\section{5. Препараты других групп}

\section{Электролиты}

Введение калия и магния считается полезным в профилактике и лечении ЖА. В частности, гипокалиемия и гипомагниемия являются весьма распространенными состояниями при $\mathrm{XCH}$ (как последствие диуретической терапии), а также при остром ИМ, что может увеличить риск появления ЖТ по типу torsades de pointes, особенно у пациентов, принимающих препараты, удлиняющие интервал QT. Именно у таких лиц внутривенное введение магния, считается терапией первой линии в борьбе с этой коварной аритмией [23].

Что же касается калия, то минимальный риск возникновения жизнеопасных вентрикулярных аритмий и ВСС наблюдается при его уровне в пределах 4,5-5,0 ммоль/л. Учитывая это, считается необходимым наблюдение за электролитным балансом крови у лиц с ЖА, особенно во время агрессивной диуретической терапии и в постинфарктном периоде [24].

Омега-3 полиненасыщенные жирные кислоты и статины

Омега-3 полиненасыщенные жирные кислоты, вероятно, могут играть положительную роль в предотвращении ВСС, посредством стабилизации мембраны билипида, связанной с поддержанием градиентов электролитов. Так, при мета-анализе обсервационных и рандомизированных исследований было показано значительное снижение случаев ВСС при регулярном потреблении омега-3 полиненасыщенных жирных кислот [25]. Это было подтверждено и в других работах, в частности у лиц, перенесших ИМ [26]. Тем не менее, в последующих исследованиях такой эффект был подвергнут сомнению, что, естественно, требует проведения новых, крупномасштабных и тщательно спланированных исследований.

Статины снижают риск развития ЖА и ВСС, связанных с ишемической болезнью сердца. Хотя механизм такого эффекта окончательно неясен, считают, что при длительном приёме они снижают степень ишемии миокарда путём уменьшения размеров старых атеросклеротических бляшек и предупреждения образования новых, что улучшает коронарный кровоток [27]. Особенности терапии больных с сердечной недостаточностью

Установлено [28], что у больных с ХСН со сФВ длительная терапия $\beta-А Б$ (в частности, бисопрололом, карведилолом, метопрололом) снижает смертность от всех причин и, в частности, связанной с жизнеопасными сердечными аритмиями. Такой же эффект оказывают и ингибиторы ангиотензин-превращающего фермента (АПФ) [29], блокаторы рецепторов ангиотензина-II (БРА) и антагонисты минералокортикоидных рецепторов (спиронолактон и эплеренон) [30, 31].

Бета-адреноблокаторы уменьшают потреб- 
ность миокарда в кислороде, снижают электрическую возбудимость и аритмогенные эффекты симпатической гиперактивности. Ингибиторы АПФ и БРА уменьшают пред- и постнагрузку на миокард, снижают потребность сердца в кислороде, блокируют образование ангиотензина-II и замедляют прогрессирование ремоделирования и фиброз миокарда желудочков. Антагонисты минералокортикоидных рецепторов ограничивают потерю организмом калия и также замедляют процессы фиброзирования миокарда. Всё это и уменьшает риск возникновения жизнеопасных ЖА [32].

Подводя итог, следует подчеркнуть, что адекватное применение ААП может оказать неоценимую помощь в профилактике и лечении жизнеопасных желудочковых нарушений сердечного ритма. При этом необходимо тщательно взвешивать предполагаемую выгоду от ААП и прогнозируемый риск развития проаритмогенного эффекта, присущего в той или иной степени фактически любому препарату [10].

\section{Н.T. Ватутин ${ }^{1,2}$, Г.Г. Тарадин ${ }^{1,2}$, Н.О. Реутова ${ }^{1}$ \\ ${ }^{1}$ ГОО ВПО «Донецкий национальный медицинский университет имени М. Горького», Донецк

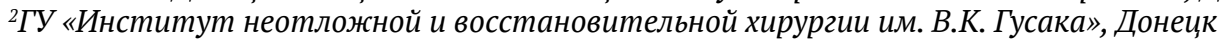

\section{МЕДИКАМЕНТОЗНАЯ ТЕРАПИЯ В ЛЕЧЕНИИ И ПРОФИЛАКТИКЕ ЖЕЛУДОЧКОВЫХ АРИТМИЙ И ВНЕЗАПНОЙ СЕРДЕЧНОЙ СМЕРТИ}

В представленном обзоре приведены современные сведения об эффективности и безопасности применения антиаритмических препаратов для лечения желудочковых нарушений ритма сердца, включая желудочковую тахикардию и фибрилляцию желудочков. На основе имеющейся классификации антиаритмических препаратов Vaughan Williams сообщается роль отдельных медикаментозных средств в лечении той или иной желудочковой аритмии. Детально освещена роль препаратов I класса, включая, в частности, лидокаин, мексилетин, хинидин, флекаинид, пропафенон и др., в лечении желудочковых аритмий, обусловленных врожденным синдромом удлиненного интервала QT, синдромом Бругада, катехоламинергической полиморфной желудочковой тахикардией. Приводятся также данные о месте в антиаритмической терапии $\beta$-адреноблокаторов и высокой эффективности препаратов III класса (прежде всего амиодарона и соталола) в лечении желудочковых аритмий. Подчеркивается ограниченность использования препаратов IV класса (верапамила и дилтиазема) в лечении аритмий желудочкового генеза. Сообщается также о механизмах и антиаритмических свойствах некоторых электролитов, омега-3 полиненасыщенных жирных кислот и статинов. Особое внимание в статье уделено особенностям антиаритмической терапии у больных с сердечной недостаточностью.

Ключевые слова: антиаритмические препараты, классификация Vaughan Williams, желудочковые аритмии. желудочковая тахикардия, фибрилляция желудочков, внезапная сердечная смерть, профилактика, лечение.

\section{N.T. Vatutin ${ }^{1,2}$, G.G. Taradin ${ }^{1,2}$, N.O. Reutova ${ }^{1}$}

${ }^{1}$ SEI HPE «M. Gorky Donetsk National Medical University», Donetsk

${ }^{2} S I$ «V.K. Gusak Institute of Urgent and Reconstructive Surgery», Donetsk

\section{DRUG TREATMENT IN THERAPY AND PREVENTION OF VENTRICULAR ARRHYTHMIAS AND SUDDEN CARDIAC DEATH}

In the presented review modern data concerning efficacy and safety of antiarrhythmic drugs administration for treatment of ventricular cardiac rhythm disorders including ventricular tachycardia and ventricular fibrillation are provided. On the basis currently available Vaughan Williams classification there are reports about a role of certain pharmacologic drugs for treatment of some or other ventricular arrhythmia. The role of antiarrhythmic drugs of I class including, in particular, lidocain, mexiletine, quinidine, flecainide, propafenone, etc. for treatment of ventricular arrhythmias induced by congenital QT prolongation syndrome, Brugada syndrome, catecholaminergic polymorphic ventricular tachycardia is highlighted in details. There are data about a place in antiarrhythmic therapy of $\beta$-blockers and high efficacy of IIIrd class antiarrhythmic drugs (mostly amiodarone and sotalol) in ventricular arrhythmia treatment. The limitation of IV class (verapamil and diltiazem) in treatment of arrhythmias of ventricular origin is emphasized. There is information about mechanisms and antiarrhythmic properties of some electrolytes, omega-3 polyunsaturated fatty acids and statins. In the article a special attention was paid to specific aspects of antiarrhythmic therapy in heart failure patients.

Key words: antiarrhythmic drugs, Vaughan Williams classification, ventricular arrhythmias, ventricular tachycardia, ventricular fibrillation, sudden cardiac death, prevention, therapy. 


\section{ЛИТЕРАТУРА}

1. Camm A.J. Hopes and disappointments with antiarrhythmic drugs. Int J Cardiol. 2017; 237: 71-74. doi:10.1016/j. ijcard.2017.03.056

2. Martin C.A., Lambiase P.D. Pathophysiology, diagnosis and treatment of tachycardiomyopathy. Heart. 2017; 103 (19): 1543-1552. doi:10.1136/heartjnl-2016-310391

3. Ватутин Н.Т., Калинкина Н.В., Гейзер Т.В., Ещенко Е.В. Об антиаритмическом эффекте $\omega-3$ полиненасыщенных жирных кислот (случай из практики). Сердце: журнал для практикующих врачей. 2014; 79 (5): $334-$ 336. doi:10.18087/rhj.2014.5.1965

4. Al-Khatib S.M., Stevenson W.G., Ackerman M.J. et al. 2017 AHA/ACC/HRS guideline for management of patients with ventricular arrhythmias and the prevention of sudden cardiac death: Executive summary. Heart Rhythm. 2018; 15 (10): e190-e252. doi:10.1016/j.hrthm.2017.10.035

5. Ватутин Н.Т., Тарадин Г.Г., Гасендич Е.С. и др. Сотрудничество кардиохирурга и кардиолога в тактике применения антиаритмических препаратов. Вестник неотложной и восстановительной хирургии. 2018; 3 (3): 234-248.

6. Williams E.M.V. A Classification of Antiarrhythmic Actions Reassessed After a Decade of New Drugs. The Journal of Clinical Pharmacology. 1984; 24 (4): 129-147. doi:10.1002/ j.1552-4604.1984.tb01822.x

7. Kudenchuk P.J., Brown S.P., Daya M. et al. Amiodarone, Lidocaine, or Placebo in Out-of-Hospital Cardiac Arrest. New England Journal of Medicine. 2016; 374 (18): 17111722. doi:10.1056/NEJMoa1514204

8. Mazzanti A., Maragna R., Faragli A. et al. Gene-Specific Therapy With Mexiletine Reduces Arrhythmic Events in Patients With Long QT Syndrome Type 3. J Am Coll Cardiol. 2016; 67 (9): 1053-1058. doi:10.1016/j.jacc.2015.12.033

9. Watanabe H., Chopra N., Laver D. et al. Flecainide prevents catecholaminergic polymorphic ventricular tachycardia in mice and humans. Nat Med. 2009; 15 (4): 380-383. doi: 10.1038/nm.1942

10. Ватутин Н.Т., Тарадин Г.Г., Гасендич Е.С. и др. О вопросах безопасности применения антиаритмических препаратов. Университетская клиника. 2018; 28 (3): 6877. doi:10.26435/UC.V0I3(28). 235

11. Gupta T., Khera S., KolteD.et al.Antiarrhythmic properties of ranolazine: A review of the current evidence. Int J Cardiol. 2015; 187: 66-74. doi:10.1016/j.ijcard.2015.03.324

12. Zareba W., Daubert J.P., Beck C.A. et al. Ranolazine in High-Risk Patients With Implanted Cardioverter-Defibrillators. J Am Coll Cardiol. 2018; 72 (6): 636-645. doi:10.1016/j.jacc.2018.04.086.

13. Curnis A., Salghetti F., Cerini M. et al. Ranolazine therapy in drug-refractory ventricular arrhythmias. Journal of Cardiovascular Medicine. 2017; 18 (7): 534-538. doi:10.2459/ JCM.0000000000000521

14. Ellison K.E., Hafley G.E., Hickey K. et al. Effect of betablocking therapy on outcome in the Multicenter UnSustained Tachycardia Trial (MUSTT). Circulation. 2002; 106 (21): 2694-2699. doi:10.1161/01.cir.0000038499.22687.39

15. Reiken S., Wehrens X.H., Vest J.A. et al. $\beta$-Blockers Restore Calcium Release Channel Function and Improve Cardiac Muscle Performance in Human Heart Failure. Circulation. 2003; 107 (19): 2459-2466. doi:10.1161/01. cir.0000068316.53218.49

16. Kontos M.C., Diercks D.B., Ho P.M. et al. Treatment and outcomes in patients with myocardial infarction treated with acute $\beta$-blocker therapy: Results from the American College of Cardiology's NCDR ${ }^{\circledR}$. Am Heart J. 2011; 161 (5): 864-870. doi:10.1016/j.ahj.2011.01.006

17. Hirsowitz G., Podrid P.J., Lampert S. et al. The role of beta blocking agents as adjunct therapy to membrane stabilizing drugs in malignant ventricular arrhythmia. Am Heart J. 1986; 111 (5): 852-860. doi:10.1016/0002-8703(86)90633-2

18. Wilde A.A., Ackerman M.J. Beta-Blockers in the Treatment of Congenital Long QT Syndrome. J Am Coll Cardiol. 2014; 64 (13): 1359-1361. doi:10.1016/j.jacc.2014.06.1192

\section{REFERENCES}

1. Camm A.J. Hopes and disappointments with antiarrhythmic drugs. Int J Cardiol. 2017; 237: 71-74. doi:10.1016/j. ijcard.2017.03.056

2. Martin C.A., Lambiase P.D. Pathophysiology, diagnosis and treatment of tachycardiomyopathy. Heart. 2017; 103 (19): 1543-1552. doi:10.1136/heartjnl-2016-310391

3. Vatutin N.T., Kalinkina N.V., Geizer T.V., Eshchenko E.V. $\mathrm{Ob}$ antiaritmicheskom effekte $\omega-3$ polinenasyshchennykh zhirnykh kislot (sluchai iz praktiki) [The anti-arrhythmic effect of $\omega-3$ polyunsaturated fatty acids (case report)]. Serdtse: zhurnal dlya praktikuyushchikh vrachei. 2014; 79 (5): 334-336. doi:10.18087/rhj.2014.5.1965 (in Russian).

4. Al-Khatib S.M., Stevenson W.G., Ackerman M.J. et al. 2017 AHA/ACC/HRS guideline for management of patients with ventricular arrhythmias and the prevention of sudden cardiac death: Executive summary. Heart Rhythm. 2018; 15 (10): e190-e252. doi:10.1016/j.hrthm.2017.10.035

5. Vatutin N.T., Taradin G.G., Gasendich E.S., et al. Sotrudnichestvo kardiokhirurga i kardiologa v taktike primeneniya antiaritmicheskikh preparatov [The cooperation of a cardiac surgeon and a cardiologist in the tactics of antiarrhythmic drugs using]. Vestnik neotlozhnoi i vosstanovitel'noi khirurgii. 2018; 3 (3): 234-248 (in Russian).

6. Williams E.M.V. A Classification of Antiarrhythmic Actions Reassessed After a Decade of New Drugs. The Journal of Clinical Pharmacology. 1984; 24 (4): 129-147. doi:10.1002/ j.1552-4604.1984.tb01822.x

7. Kudenchuk P.J., Brown S.P., Daya M. et al. Amiodarone, Lidocaine, or Placebo in Out-of-Hospital Cardiac Arrest. New England Journal of Medicine. 2016; 374 (18): 17111722. doi:10.1056/NEJMoa1514204

8. Mazzanti A., Maragna R., Faragli A. et al. Gene-Specific Therapy With Mexiletine Reduces Arrhythmic Events in Patients With Long QT Syndrome Type 3. J Am Coll Cardiol. 2016; 67 (9): 1053-1058. doi:10.1016/j.jacc.2015.12.033

9. Watanabe H., Chopra N., Laver D. et al. Flecainide prevents catecholaminergic polymorphic ventricular tachycardia in mice and humans. Nat Med. 2009; 15 (4): 380-383. doi: 10.1038/nm.1942

10. Vatutin N.T., Taradin G.G., Gasendich E.S., et al. O voprosakh bezopasnosti primeneniya antiaritmicheskikh preparatov [About safety concerns of antiarrhythmic drugs administration] Universitetskaya klinika. 2018; 28 (3): 68-77. doi:10.26435/UC.V0I3(28).235 (in Russian).

11. GuptaT., Khera S., KolteD.et al.Antiarrhythmic properties of ranolazine: A review of the current evidence. Int J Cardiol. 2015; 187: 66-74. doi:10.1016/j.ijcard.2015.03.324

12. Zareba W., Daubert J.P., Beck C.A. et al. Ranolazine in High-Risk Patients With Implanted Cardioverter-Defibrillators. J Am Coll Cardiol. 2018; 72 (6): 636-645. doi:10.1016/j.jacc.2018.04.086.

13. Curnis A., Salghetti F., Cerini M. et al. Ranolazine therapy in drug-refractory ventricular arrhythmias. Journal of Cardiovascular Medicine. 2017; 18 (7): 534-538. doi:10.2459/ JCM.0000000000000521

14. Ellison K.E., Hafley G.E., Hickey K. et al. Effect of betablocking therapy on outcome in the Multicenter UnSustained Tachycardia Trial (MUSTT). Circulation. 2002; 106 (21): 2694-2699. doi:10.1161/01.cir.0000038499.22687.39

15. Reiken S., Wehrens X.H., Vest J.A. et al. $\beta$-Blockers Restore Calcium Release Channel Function and Improve Cardiac Muscle Performance in Human Heart Failure. Circulation. 2003; 107 (19): 2459-2466. doi:10.1161/01. cir.0000068316.53218.49

16. Kontos M.C., Diercks D.B., Ho P.M. et al. Treatment and outcomes in patients with myocardial infarction treated with acute $\beta$-blocker therapy: Results from the American College of Cardiology's NCDR ${ }^{\circledR}$. Am Heart J. 2011; 161 (5): 864-870. doi:10.1016/j.ahj.2011.01.006

17. Hirsowitz G., Podrid P.J., Lampert S. et al. The role of beta blocking agents as adjunct therapy to membrane stabilizing drugs in malignant ventricular arrhythmia. Am Heart J. 1986; 111 (5): 852-860. doi:10.1016/0002-8703(86)90633-2 
19. Steinberg J.S., Martins I., Sadanandan S, et al. Antiarrhythmic drug use in the implantable defibrillator arm of the Antiarrhythmics Versus Implantable Defibrillators (AVID) Study. Am Heart J. 2001;142 (3): 520-529. doi:10.1067/mhj.2001.117129

20. Claro J.C., Candia R., Rada G. et al. Amiodarone versus other pharmacological interventions for prevention of sudden cardiac death. Cochrane Database of Systematic Reviews. 2015. 2015; 8 (12): CD008093. doi:10.1002/14651858. CD008093.pub2

21. Dorian P., Cass D., Schwartz B. Amiodarone as compared with lidocaine for shock-resistant ventricular fibrillation. ACC Current Journal Review. 2002; 11 (4): 82. doi:10.1016/ s1062-1458(02)00736-5

22. Badhwar N., Scheinman M.M. Idiopathic Ventricular Tachycardia:Diagnosis and Management. Curr Probl Cardiol. 2007; 32 (1): 7-43. doi:10.1016/i.cpcardiol.2006.10.002

23. Antman E.M. Early administration of intravenous magnesium to high-risk patients with acute myocardial infarction in the Magnesium in Coronaries (MAGIC) Trial: a randomised controlled trial. The Lancet. 2002; 360 (9341): 1189-1196. doi:10.1016/s0140-6736(02)11278-5

24. Goyal A., Spertus J.A., Gosch K. et al. Serum potassium levels and mortality in acute myocardial infarction. JAMA. 2012; 307 (2): 157-164. doi:10.1001/jama.2011.1967

25. Rauch B., Schiele R., Schneider S. et al. OMEGA, a randomized, placebo-controlled trial to test the effect of highly purified omega- 3 fatty acids on top of modern guideline-adjusted therapy after myocardial infarction. Circulation. 2010; 122 (21): 2152-2159. doi:10.1161/ CIRCULATIONAHA.110.948562

26. Bosch J., Gerstein H.C., Dagenais G.R. et al. n-3 fatty acids and cardiovascular outcomes in patients with dysglycemia. N Engl J Med. 2012; 367 (4): 309-318. doi:10.1056/ NEJMoa1203859

27. Buber I., Goldenberg I., Moss A.J. et al. Reduction in lifethreatening ventricular tachyarrhythmias in statin-treated patients with nonischemic cardiomyopathy enrolled in the MADIT-CRT (Multicenter Automatic Defibrillator Implantation Trial with Cardiac Resynchronization Therapy). J Am Coll Cardiol. 2012; 60 (8): 749-755. doi:10.1016/j. jacc.2012.03.041

28. Yancy C.W., Jessup M., Bozkurt B. et al. 2016 ACC/AHA/ HFSA Focused Update on New Pharmacological Therapy for Heart Failure: An Update of the 2013 ACCF/AHA Guideline for the Management of Heart Failure. J Am Coll Cardiol. 2016; 68 (13): 1476-1488. doi:10.1016/i.jacc.2016.05.011

29. Cohn J.N., Johnson G., Ziesche S. et al. A Comparison of Enalapril with Hydralazine-Isosorbide Dinitrate in the Treatment of Chronic Congestive Heart Failure. New England Journal of Medicine. 1991; 325 (5): 303-310. doi:10.1056/nejm199108013250502

30. Pitt B., Remme W., Zannad F. et al. Eplerenone, a Selective Aldosterone Blocker, in Patients with Left Ventricular Dysfunction after Myocardial Infarction. New England Journal of Medicine. 2003; 348 (14): 1309-1321. doi:10.1056/ nejmoa030207

31. Al Chekakie M.O. Traditional heart failure medications and sudden cardiac death prevention: a review. J Cardiovasc Pharmacol Ther. 2013; 18 (5): 412-426. doi:10.1177/1074248413491496

32. Pfeffer M.A., McMurray J.J., Velazquez E.J. et al. Valsartan, Captopril, or Both in Myocardial Infarction Complicated by Heart Failure, Left Ventricular Dysfunction, or Both. New England Journal of Medicine. 2003; 349 (20): 1893-1906. doi:10.1056/nejmoa032292
18. Wilde A.A., Ackerman M.J. Beta-Blockers in the Treatment of Congenital Long QT Syndrome. J Am Coll Cardiol. 2014; 64 (13): 1359-1361. doi:10.1016/j.jacc.2014.06.1192

19. Steinberg J.S., Martins J., Sadanandan S. et al. Antiarrhythmic drug use in the implantable defibrillator arm of the Antiarrhythmics Versus Implantable Defibrillators (AVID) Study. Am Heart J. 2001;142 (3): 520-529. doi:10.1067/mhj.2001.117129

20. Claro J.C., Candia R., Rada G. et al. Amiodarone versus other pharmacological interventions for prevention of sudden cardiac death. Cochrane Database of Systematic Reviews. 2015. 2015; 8 (12): CD008093. doi:10.1002/14651858. CD008093.pub2

21. Dorian P., Cass D., Schwartz B. Amiodarone as compared with lidocaine for shock-resistant ventricular fibrillation. ACC Current Journal Review. 2002; 11 (4): 82. doi:10.1016/ s1062-1458(02)00736-5

22. Badhwar N., Scheinman M.M. Idiopathic Ventricular Tachycardia: Diagnosis and Management. Curr Probl Cardiol. 2007; 32 (1): 7-43. doi:10.1016/j.cpcardiol.2006.10.002

23. Antman E.M. Early administration of intravenous magnesium to high-risk patients with acute myocardial infarction in the Magnesium in Coronaries (MAGIC) Trial: a randomised controlled trial. The Lancet. 2002; 360 (9341): 1189-1196. doi:10.1016/s0140-6736(02)11278-5

24. Goyal A., Spertus J.A., Gosch K. et al. Serum potassium levels and mortality in acute myocardial infarction. JAMA. 2012; 307 (2): 157-164. doi:10.1001/jama.2011.1967

25. Rauch B., Schiele R., Schneider S. et al. OMEGA, a randomized, placebo-controlled trial to test the effect of highly purified omega- 3 fatty acids on top of modern guideline-adjusted therapy after myocardial infarction. Circulation. 2010; 122 (21): 2152-2159. doi:10.1161/ CIRCULATIONAHA.110.948562

26. Bosch J., Gerstein H.C., Dagenais G.R. et al. n-3 fatty acids and cardiovascular outcomes in patients with dysglycemia. N Engl J Med. 2012; 367 (4): 309-318. doi:10.1056/ NEJMoa1203859

27. Buber J., Goldenberg I., Moss A.J. et al. Reduction in lifethreatening ventricular tachyarrhythmias in statin-treated patients with nonischemic cardiomyopathy enrolled in the MADIT-CRT (Multicenter Automatic Defibrillator Implantation Trial with Cardiac Resynchronization Therapy). J Am Coll Cardiol. 2012; 60 (8): 749-755. doi:10.1016/j. jacc.2012.03.041

28. Yancy C.W., Jessup M., Bozkurt B. et al. 2016 ACC/AHA/ HFSA Focused Update on New Pharmacological Therapy for Heart Failure: An Update of the 2013 ACCF/AHA Guideline for the Management of Heart Failure. J Am Coll Cardiol. 2016; 68 (13): 1476-1488. doi:10.1016/j.jacc.2016.05.011

29. Cohn J.N., Johnson G., Ziesche S. et al. A Comparison of Enalapril with Hydralazine-Isosorbide Dinitrate in the Treatment of Chronic Congestive Heart Failure. New England Journal of Medicine. 1991; 325 (5): 303-310. doi:10.1056/nejm199108013250502

30. Pitt B., Remme W., Zannad F. et al. Eplerenone, a Selective Aldosterone Blocker, in Patients with Left Ventricular Dysfunction after Myocardial Infarction. New England Journal of Medicine. 2003; 348 (14): 1309-1321. doi:10.1056/ nejmoa030207

31. Al Chekakie M.O. Traditional heart failure medications and sudden cardiac death prevention: a review. J Cardiovasc Pharmacol Ther. 2013; 18 (5): 412-426. doi:10.1177/1074248413491496

32. Pfeffer M.A., McMurray J.J., Velazquez E.J. et al. Valsartan, Captopril, or Both in Myocardial Infarction Complicated by Heart Failure, Left Ventricular Dysfunction, or Both. New England Journal of Medicine. 2003; 349 (20): 1893-1906. doi:10.1056/nejmoa032292 